\title{
Complexidade e compreensão em reportagens sobre a migração de refugiados africanos: a narrativa jornalística de Paulo Moura
}

Mauro de Souza Ventura ${ }^{1}$, Tayane Aidar Abib²

1 Professor adjunto do Departamento de Comunicação Social da Universidade Estadual Paulista (Unesp). LivreDocente em Jornalismo. Doutor em Teoria Literária e Literatura Comparada pela Universidade de São Paulo (USP). E-mail: ms.ventura@unesp.br. 


\section{Resumo}

Dados da Agência de Refugiados das Nações Unidas (UNHCR) indicam que, todos os dias, 44.400 pessoas são forçadas a fugir de suas casas devido a perseguições, conflitos ou violência generalizada. Este artigo investiga caminhos narrativos possíveis para a cobertura da crise dos refugiados, propondo a adoção de dispositivos que entrelaçam complexidade e compreensão à prática jornalística. Analisa, neste sentido, o trabalho de reportagem do jornalista português Paulo Moura em cenários de crise migratória, evidenciando, especificamente em sua obra Passaporte para o céu (2005), as perspectivas de diálogo e afetos que, circunscritas à esfera da alteridade, são tecidas acerca da realidade dos africanos que buscam alcançar a Europa.

\section{Palavras-chave}

Narrativa jornalística, epistemologia complexo-compreensiva, refugiados, África, Paulo Moura.

\section{Abstract}

Statistics from the United Nations Refugee Agency (UNHCR) indicate that, every day, 44,400 people are forced to leave their homes, because of persecution, conflict or widespread violence. This article investigates possible narrative ways of covering the refugee crisis, proposing the adoption of devices that link complexity and comprehensive to journalistic practice. It analyzes, in this sense, the work of the Portuguese journalist Paulo Moura on scenarios of the migratory crisis, evidencing, specifically in his work Passport to heaven (2005), the perspectives of dialogue and affections that, circumscribed to the sphere of otherness, are woven about the reality of the Africans that seek to reach Europe.

\section{Keywords}

Journalism narrative, complex-comprehensive epistemology, refugees, Africa, Paulo Moura. 


\section{Introdução}

A crise dos refugiados nos interpela todos os dias. Dados estatísticos, imagens e manchetes alarmantes anunciam, por diferentes plataformas midiáticas, a luta pela sobrevivência de uma humanidade tão desejosa de progresso e, ainda assim, mais disposta a erguer muros que construir pontes, mais interessada em destruir a diversidade que a reconhecer que compartilhamos uma natureza comum. A nave Terra, alerta Edgar Morin (2003, p. 19), "navega pela noite bruma numa aventura desconhecida", enquanto o homem resiste a aceitar que o problema que afeta a cultura contemporânea é da ordem da relação: "reencontrar-se consigo mesmo, reencontrar no outro a origem e o complemento essencial de si mesmo, restabelecer a paz com o corpo, com o alter e com a natureza" (MORIN, 2003, p. 10).

Ano a ano, a Agência de Refugiados das Nações Unidas (UNHCR) nos fornece relatórios com os indicativos da nova realidade mundial: em 2017, a população deslocada à força aumentou em 2,9 milhões, totalizando em 68,5 milhões o número de pessoas desalojadas no mundo naquele último ano. Devido a perseguições, conflitos ou violência generalizada, estima-se que, todos os dias, uma média de 44.400 pessoas está sendo forçada a fugir de casa. Hoje, um em cada 110 indivíduos no mundo está deslocado, e cerca de metade da população refugiada é de pessoas com menos de 18 anos (UNHCR, 2017).

A despeito desse vasto catálogo de desgraça e de injustiça que nos é apresentado rotineiramente, parece-nos quase impossível apreender a realidade de dor do Outro. O mundo hipersaturado com registros do horror só consegue nos oferecer, diz-nos Sontag (2003, p. 52), "certa familiaridade com o choque, levando o horrível a parecer mais comum - levando-o a parecer familiar, distante, inevitável". Existiria um modo, questiona a autora norte-americana, de deixar uma marca mais funda, no que diz respeito ao relato dessas atrocidades?

Acompanhando essas inquietações, na esteira das reflexões sobre a crise humanitária que aflige nosso século, dedicamo-nos a investigar o potencial simbólico da narrativa jornalística enquanto "uma das respostas humanas diante do caos" (MEDINA, 2006, p. 67). Especificamente, concentramo-nos na 
obra Passaporte para o céu, publicada pelo jornalista português Paulo Moura, em 2005, que registra a travessia de imigrantes africanos que tentam chegar clandestinamente às costas da Espanha.

Nessas histórias pungentes e reveladoras da contemporaneidade, buscamos identificar os dispositivos narrativos de uma prática jornalística alinhada à Epistemologia Complexo-Compreensiva, elucidada por Künsch (2005, p. 53), na expectativa de nela enxergar a tarefa característica "de costurar nexos entre informações que, isoladas e numerosas, quais árvores a impedir uma visão do bosque, não permitem uma compreensão abrangente dos sentidos de uma época". Sob a configuração de um relato que, segundo Kramer (2005, p. 5), é outro do modelo convencional, "porque trata do rotineiro, das esquinas obscuras do planeta que precisamos de conhecer, se queremos pensar lucidamente o nosso mundo", esperamos, por fim, situar tal modus operandi como caminho possível para a tessitura de reportagens sensíveis à narrativa dos refugiados.

\section{No jogo complexo-compreensivo, possibilidades outras de tessitura jornalística}

A expectativa do presente artigo é discorrer sobre possibilidades narrativas em cenário de conflitos e crise migratória de refugiados, como a que se observa no continente africano. Para tanto, acionaremos, em um primeiro momento, a perspectiva epistemológica defendida por Künsch (2005), que associa as concepções de complexidade e compreensão (MORIN, 2002; MORIN; WULF, 2003) e as insere no terreno das práticas jornalísticas.

A ideia de progresso, sob o tripé ciência/técnica/indústria, que sustentou a marcha da história moderna, encontra-se cada vez mais em xeque, segundo Morin (2003). A deflagração das duas guerras mundiais, no século XX, escancararam a radical ambivalência de suas promessas, fazendo "regressar à barbárie as nações mais avançadas" (p. 14).

Percebe-se que o individualismo significa não apenas autonomia e emancipação, como também atomização e anonimização. A secularização significa não só a libertação dos dogmas religiosos, mas também a perda 
dos valores, a angústia e a incerteza. A diferenciação dos valores conduz não somente à autonomia moral, ao prazer estético e à livre busca da verdade, mas igualmente à amoralidade, ao estetismo frívolo e ao niilismo. (MORIN, 2003, p. 17)

Como resposta à crise da noção de progresso, o autor francês contrapõe o pensamento complexo, que comporta a fragilidade e o sentimento, agudo ou difuso, do incerto. Diante da ameaça do perigo da destruição da biosfera, das catástrofes demográficas e mesmo da proliferação atômica, que nos desperta para a consciência do caráter desconhecido que, pela primeira vez, vive a humanidade, Morin (2003, p. 27) indica que "o que falta é a capacidade de contextualizar e de globalizar". A mundialização, ou a era planetária, iniciada no final do século XV, com as viagens de Cristóvão Colombo e de Vasco da Gama, coloca-nos em comunicação, cada vez mais acelerada e ampliada pelo impulso técnico da Europa ocidental, com o mundo todo. Ainda assim, observamos a tendência "onde as etnias, as nações e as religiões frequentemente se fecham em si mesmas; ou seja, se veem como o centro do mundo, onde a parte se julga mais importante que o todo" (MORIN, 2003, p. 27).

Eis, então, o nosso paradoxo, de acordo com Morin: vivemos numa época em que tudo está inter-relacionado, mas "não há nenhuma consciência pertinente que seja válida se não tiver pelo menos o mundo como horizonte para todos os grandes problemas" (MORIN, 2003, p. 27). Isso porque somos herdeiros de um paradigma de hipersimplificação, de "uma inteligência cega que destrói os conjuntos e as totalidades, isola todos os seus objetos do seu meio ambiente" (MORIN, 2007, p. 12), e que nos leva a negligenciar o contexto da informação, assim segmentando, "como em fatias de presunto, os aspectos do mundo" (MORIN, 2003, p. 28).

A isso, acrescenta-se nossa dificuldade em valorar o elemento mais importante da racionalidade ocidental, sob a ótica de Morin: a nossa faculdade autocrítica. 
estranho. Eu diria que isso se aplica também a cada um em relação a si mesmo, porque ninguém é mais estranho do que cada um para si mesmo. Antes, reconhecíamos o valor da introspecção. E hoje, em nome da psicologia objetiva, eliminamos o autoexame, tão importante porque compreendemos que há um outro nós mesmos e que há um desconhecido em nós. (MORIN, 2003, p. 35, grifos do autor)

Evidencia-se, neste sentido, a episteme que torna a complexidade companheira indissociável da compreensão, na defesa de um pensamento democrático: complexo, ao exercitar a escuta e se fortalecer na interface com o contraditório e o antagônico, e compreensivo, ao reforçar os sentidos dialógicos, de não-arrogância e de não-violência. Inscrita no universo das práticas jornalísticas, a epistemologia complexo-compreensiva pode fundamentar uma ética cognitiva capaz de valorizar a problematização e fomentar o signo da relação interpessoal. Quando o repórter rompe com a objetividade e a racionalidade positivista, abre-se à pluralidade às múltiplas causas e dimensões do humano. Abandona, assim, a visão estreita, a tendência à explicação, o condicionamento à padronização, lançandose às narrativas nas quais se compreende, tal qual nos diz Martino (2010, p. 7), "se abraça, se entende o espaço intersubjetivo no qual todos estamos".

Pela guinada complexo-compreensiva, portanto, sublinha-se os limites e entraves de um modus operandi jornalístico do tipo reducionista. O que se está a defender é o poder da narrativa, à luz da acepção assumida no início dessa investigação, "de reinventar os sentidos que reconstroem o cosmos em meio ao caos eterno da existência" (KÜNSCH, 2010, p. 27). Quer-se lançar ao cenário das possibilidades textos polifônicos e polissêmicos, de renúncia ao legado racionalizador da modernidade, como um marco de resistência ao analfabetismo afetivo - que orienta a cultura ocidental e dificulta a enunciação de um discurso sobre a ternura (RESTREPO, 1998, p. 21).

Enveredando-se por essas vias, o jornalismo assume os contornos do princípio dialógico de que fala Buber (1982), situando-se no terreno da alteridade, "na colação do sentido de 'eu' ao outro" (LÉVINAS, 1997, p. 123), sob o movimento que desperta à descoberta de uma responsabilidade pelo outro: "eu me vejo 
a partir do outro, exponho-me a outrem, tenho contas a prestar". Na entrevista que se faz encontro genuíno, a técnica é superada por uma intimidade entre o Eu e o Tu, afirma Medina (2008, p. 7). Elucida-se "determinada autocompreensão ou compreensão do mundo":

Reportagem, no seu tríplice potencial de razão analítica, ação solidária e intuição sintético-afetiva, experimenta caminhos inovadores na mediação social. Experimenta além da participante da antropologia, sempre que o encontro com o Outro e sua circunstância se dá não exclusivamente pela técnica da entrevista ou coleta de depoimentos. A autoria na mediação social acontece no contato presencial, sempre um mistério e uma possibilidade de transformação dos atores em relação. (MEDINA, 2016, p. 23)

O 'eu', desta forma, somente emerge do encontro com o Outro. É a alteridade, conforme pontuam Morin e Wulf (2003, p. 78), que "está na origem" e é necessária para "que cada um se torne si mesmo". Sob este viés, a necessidade do Outro é radical, "mostra a incompletude do Ego/Eu sem reconhecimento" e nos recorda de nossa própria estranheza - essa que, segundo os autores, "é uma experiência essencial, pois permite abrir-nos às outras culturas" (MORIN; WULF, 2003, p. 36, grifo dos autores).

É nesta chave de reflexão que Kristeva (1994, p. 9) também discute a problemática do estrangeiro. "Símbolo do ódio e do outro", escreve a pensadora búlgaro-francesa, "o estrangeiro habita em nós, é a face oculta de nossa identidade $[. .$.$] , começa quando surge a consciência de minha diferença e termina$ quando nos reconhecemos todos estrangeiros". Pela consciência de nossa estranheza se faz possível, neste sentido, reconhecer o Outro não somente como desconhecido, mas como sujeito que pode "sofrer como nós, amar como nós, chorar como nós" (MORIN, 2003, p. 35) - na convivência harmoniosa das diferenças.

Identifica-se em tal perspectiva, por isso, caminhos abertos a tessituras narrativas que, na dinâmica da complexidade e da compreensão, busquem escutar as múltiplas vozes e apreender os múltiplos sentidos que compõem o mosaico sociocultural da contemporaneidade. Especificamente, espera-se, aqui, sublinhar no trabalho de reportagem de Paulo Moura a presença desses 
dispositivos dialógico-afetivos a registrar, e sensibilizar sobre, a crise migratória dos refugiados do continente africano.

\section{Mais além da cobertura jornalística convencional: a narrativa sobre os camarades de Paulo Moura}

Com uma trajetória profissional marcada por 23 anos de contribuição ao jornal português Público, Paulo Moura, atualmente jornalista freelancer, consagrouse por sua atuação em zonas de conflito em todo o mundo, especialmente em países da África e da Ásia, acumulando prêmios e reconhecimento internacional na área de Direitos Humanos. Assumindo-se como um repórter sem especialização, que "procura as situações que são menos conhecidas, o lado humano, essa dimensão de observar o comportamento naquilo que é a construção de uma narrativa" (MOURA, 2017), Moura se interessa pelo simbolismo manifesto nas vidas supostamente comuns, em uma prática que dialoga com a acepção noticiosa da jornalista brasileira Eliane Brum (2013, p. 197), que escreve que se tornou repórter para "descobrir o que dá sentido à existência de cada um e para compreender como cada pessoa - em geral com muito pouco - reinventa sua história".

A mirada sensível aos fatos não-marcados pela noticiabilidade convencional, àqueles que, segundo Sodré (2009, p. 76), não são "imediatamente relevantes para o cânone da cultura jornalística, normalmente desconsiderados pela marcação (pauta) da grande mídia", caracteriza o exercício narrativo de Paulo Moura, a insistir, tal qual diz Maffesoli (2010, p. 65), "na nobreza da vida cotidiana", nesse "ordinário em que é elaborado o conhecimento do social". Nas ruas das grandes cidades ou nas vielas de povoados, em Portugal ${ }^{3}$ ou ao redor do mundo ${ }^{4}$, seus textos se articulam por sua "grande curiosidade em tentar compreender os outros, mesmo aqueles dos primeiros jovens fundamentalistas na Argélia, em 1991, ao crescimento de sua influência na Tchetchénia, em Caxemira, no Kosovo, no Afeganistão, no Iraque, no Sudão e nas capitais europeias. Trata, também, da Primavera Árabe, em 2011, e da crise dos refugiados sírios. 
que são completamente diferentes de mim, e dar-Ihes o mesmo crédito que dou às pessoas de quem eu gosto e com quem concordo" (MOURA, 2017).

Seu trabalho de reportagem é, neste sentido, imersivo, operando sob uma lógica comunicacional para além da simples coleta e transmissão de informações: "significa ficar lá para experimentar, sentir, viver as situações tal como os protagonistas as vivem" (MOURA, 2017) - tal qual concebe Marcondes Filho (2002, p. 88): "sentir junto, participar da existência do outro, conhece-lo, mesmo que ele não diga, mesmo em seu silêncio [...] o mais denso e profundo que se possa imaginar".

É essa conduta que sustenta o ofício narrativo de Moura na obra Passaporte para o céu (2005), uma grande reportagem que relata o dia a dia de imigrantes subsaarianos nos arredores de Tânger, na floresta de Missnana, no sonho de cruzar a fronteira de Ceuta e alcançar a Europa, e também daqueles que, já tendo chegado a esse ceú, "encontraram uma história interminável. Encontraram o inferno" (MOURA, 2005, p. 9).

Passei dias com os imigrantes [...]. Assisti à missa de domingo, numa clareira de Missnana, ouvi os que ficaram doentes ou feridos, os que foram assaltados ou deportados dez vezes e voltaram a pé. Entrevistei os pastores evangélicos, os líderes africanos e os mafiosos marroquinos. Segui, até a estrada de Marbella, na Andaluzia, até à praça do Intendente, em Lisboa, as nigerianas condenadas à prostituição pelos seus contratos com a máfia. O dossier de notícias e estatísticas transformou-se, para mim, na história dos "camarades". A história que não consigo acabar. (MOURA, 2005)

Do outro lado do mar de Portugal, Moura se dedica a acolher as histórias arrebatadoras que contam sobre a realidade dos refugiados do nosso século, e que dificilmente o aparato convencional do jornalismo tradicional consegue trazer à tona - Mark Kramer (2005, p. 5), no prefácio do livro, nos dá pistas do porquê: "[os personagens] são estrangeiros, numa época de declínio das coberturas noticiosas internacionais, e pobres, numa época em que são os ricos que nos fascinam, e porque o seu terrível dilema se tornou uma rotina, numa imprensa sedenta de novidades, não tem havido muito a dizer". 
Alinhado ao movimento intersubjetivo que engendra a dinâmica complexocompreensiva no contexto da reportagem, Paulo Moura busca se aproximar das vidas que, ainda que estranhas a sua, recordam-nos "de nossa aptidão não em aceitar o outro, mas de estar em seu lugar - o que equivale a pensar sobre si e a se fazer outro para si mesmo" (KRISTEVA, 1994, p. 21). Na abertura empática aos camarades - denominação dos marroquinos aos africanos que tentam chegar à Europa -, Moura (2005, p. 12) relata o que experenciou "através do olhar opaco dos heróis, dos que já vivem na Europa" e também o que entreviu "nos caminhos secretos dos imigrantes, os caminhos que não levam a lugar nenhum".

Subverte, assim, com seu registro acerca das memórias e motivações desses migrantes, o posicionamento que comumente assola as relações com o estrangeiro:

Ninguém o escuta, a palavra jamais é sua. [...] Por que a escutariam? Você não tem cacife suficiente - não tem "peso social" - para tornar a sua palavra útil. Ela pode ser desejável, surpreendente também, estranha ou atraente, até. Porém tais atrativos têm um peso fraco diante do interesse - que falta, precisamente - dos interlocutores. (KRISTEVA, 1994, p. 28, grifo da autora)

Ao relatar o percurso desses indivíduos que vão e voltam, dos migrantes que chegam ilegalmente e daqueles que legalmente regressam à África para férias, o repórter português realça os meandros do encontro entre vida e utopia mobilizando os afetos, seus e de seus leitores, na tentativa de compreender o rosto desse estrangeiro que, nas palavras de Kristeva (1994, p. 10, grifo da autora), "queima a felicidade [...], destaca e [nos] lembra que ali existe alguém". Esforçase, neste sentido, em revelar o essencial que apenas um olhar atento consegue apreender: "a inexistência da banalidade entre os seres humanos" (idem).

Tento imaginar o que sente um recém-chegado imigrante magrebino ou subsaariano. Eis a Europa, pensará ele. Eis o Céu, clamará, procurando avidamente entre o lixo da rua e os restos da sua ilusão. Caminhará sobre as ruinas do seu próprio sonho e a cidade à frente dos seus olhos não será esta. Mas outra. Pura ficção. (MOURA, 2005, p. 16) 
Na floresta de Missnana, convivendo entre aqueles que esperam um barco para, clandestinamente, fazerem a travessia até a costa espanhola, Moura registra a realidade daquelas vidas que parecem "indignas de serem vividas", o homo sacer, de que fala Agamben (2004, p. 149): "extrema metamorfose da vida matável e insacrificável sobre a qual se baseia o poder soberano". O filósofo italiano faz alusão a esse termo romano para se referir aos homens que, destituídos de qualquer amparo a seu favor, estão condicionados a uma vida nua, isto é, desqualificada de dimensões biológicas e sociais, situadas numa espécie de limiar entre a vida e a morte - fora tanto do direito humano, quanto daquele divino.

O homo sacer vive, assim, sob um caráter de dupla exclusão, cuja estrutura se materializa não apenas em Estados de exceção, com os campos de concentração, mas que pode ser reproduzida e revivida em outros locais, como interpreta Biondi (2013, p. 89): "no mundo atual, é a própria inscrição da vida nua que regula o funcionamento de um campo sem que o local determine sua realização, mas é através de sua realização que se determina o campo precisamente".

Essa natureza replicante faz com que a realidade do refugiado se insira, também, nesse limbo de não-vida e de não-morte, com que vivam aprisionados nessa estrutura que convoca, tal qual diz Kristeva (1994, p. 10), "a uma viagem inacessível, exasperante, cujo código o estrangeiro não possui, mas cuja memória silenciosa, física, visível, ele guarda". Quando Moura (2005) reporta esses sujeitos sofredores que aguardam meses, por vezes anos, para tentar realizar o trajeto até a Europa, como é o caso de Livingstone, que, com outras trinta pessoas, partiu da Nigéria em um caminhão, atravessando Benim, Níger, Mali e Argélia, até entrar no Marrocos, é possível apreender, no plano da escritura, tais apontamentos teóricos:

"Nós sonhamos ser europeus, mas nunca o seremos. Mas também nunca nos sentiremos bem em sermos como somos, africanos. O que é ser-se africano? Não sei. Ninguém sabe. É mais um não-ser qualquer coisa. É um mal-estar. É sempre uma procura. Os africanos que vão para a Europa nunca são europeus. Por mais êxito que tenham. Só são europeus quando estão em África e se querem diferenciar dos seus compatriotas. Cada um de nós traça o seu próprio caminho, mas é um caminho imaginário. Depois, não fazemos mais do que avançar pelo labirinto que inventamos" [...]. E Livingstone pensou 
que também emigrar é fugir para onde não há refúgio, fugir de si próprio. Perseguir um sonho que nos rejeita. (MOURA, 2005, p. 102)

Seu convívio com os camarades busca dar conta da complexidade de sensações que habita o imaginário e a brutalidade dos dias daqueles que decidem, a dois mil euros cada um, embarcar em um "zodiac" clandestinamente, como se evidencia nos relatos de Michael, Juja e Jonathan. Há dois anos e meio enfrentando fome, agressões e enfermidades em Missnana, seus percursos rumo ao estreito de Gibraltar representam também a concretização das expectativas da família, como indica Michael: "eu sou sua grande esperança, fui o único dos meus irmãos a ter a oportunidade. Foi uma espécie de investimento que fizeram, meu pai vendeu o único bem que possuía, uma casa que temos há várias gerações" (MOURA, 2005, p. 109). Agora, a arder em febre, não tem como contatá-los e explicar que o dinheiro reservado para lhes assegurar um novo destino foi tomado em assaltos, "tarifas", "impostos" e "comissões": "eles pensam que já estou há muito na Europa, a ganhar dinheiro para Ihes enviar" (MOURA, 2005, p. 109).

Juja, que tem 39 anos e asma, prometeu aos pais, mortos na guerra em Serra Leoa, que teria uma vida diferente: "levei cinco anos a chegar em Marrocos. Caminhava, parava, trabalhava, continuava a caminhar. Cinco anos, pelo deserto... Posso ser deportado, e morrerei de asma. Nunca tive isto. Mas começou quando vim para a floresta [...] Talvez não suporte o próximo ataque" (MOURA, 2005, p. 114). Entre a procura por medicamentos e o medo de não saber até quando aguentará, são as projeções de um cotidiano distinto que lhe movem a persistir: "é a minha sina, eu vou chegar à Europa. Posso trabalhar. Sei vulcanizar um pneu. Sei rebobinar um motor eléctrico. Sei conduzir camiões e máquinas. Eu vou chegar à Espanha, e eles, lá, sabem que eu vou chegar" (MOURA, 2005, p. 115).

Nas palavras de Jonathan, 29 anos, cuja família esteve envolvida em negócios ilegais para obter dinheiro suficiente para sua viagem, a chegada ao novo continente é que poderá lhes proporcionar um recomeço: "eu sei que se chegar à Europa conseguirei tudo [...]. Vocês, no cristianismo, acreditam no Céu, não é? Pois, para mim, o Céu é a Europa" (2005, p. 115). 
Pela acepção noticiosa de conferir protagonismo às histórias de vida, a partir do registro do testemunho sobre o que pensam e sentem os indivíduos migrantes, Moura inscreve o ofício jornalístico enquanto signo da relação (MEDINA, 2006) movimento empático ao Outro, que nos vincula em dialogia e nos permite conhecer suas tramas em primeira pessoa. Aciona a dimensão do sensível, de que fala Sodré (2006, p. 11), "uma estratégia de aproximação das diferenças - decorrente de um ajustamento afetivo, somático, entre as partes diferentes num processo", e que se vale da escuta para uma abertura à alteridade.

Reconhecer a singularidade do Outro, como escreve Martino (2010, p. 9), sob uma ética da alteridade "que pode até mesmo não aceitar suas razões do outro, mas considera a validade dessas razões, isto é, atinge o espaço da compreensão desse ser-outro com quem se interage".

Esse é, precisamente, o desafio de um jornalismo complexo-compreensivo: narrar o mundo a partir do Outro, "sem destruí-lo no processo - e, se preciso, explodir as fronteiras para acomodar o ser" (MARTINO, 2010, p. 9). Nesta configuração que destaca as vozes tradicionalmente marginalizadas pelo interesse público e midiático, há, ainda, um posicionamento discursivo que interpela os interlocutores sobre suas responsabilidades e omissões: "na Europa, há alguém a viver em arbustos? O mundo sabe que aqui se passa fome? Que vivem sem tecto, no inverno, à chuva e a frio? Que são objeto de caçadas, de matanças?" (MOURA, 2005, p. 87).

A experiência-vivência do repórter junto à realidade local o implica a abordar a luta pela sobrevivência dos refugiados em chave narrativa densa, assinalando percepções e detalhes que, desde as vias da humanização, nos ajudam a empreender a alter locução, isto é, pensar sobre o que vive o Outro a partir do que eu sentiria sob a mesma situação:

Eles vivem em "zangas", palavra árabe marroquino para tendas. A "zanga" não tem qualquer proteção, não é lugar algum. Só a presença do "inquilino" faz dela uma "casa". Quando chove, torna-se chafurdeiros de lama gelada. "E como se dorme?", pergunto. "Na mesma. Ficamos molhados", responde George Clifford, que está em Missnana há meses. "E secam-se como?". "Não nos secamos, ficamos assim". "E o frio?". 
"É horrível, ficamos doentes". "E que vem para vos tratar?". "Ninguém. Continuamos doentes". (MOURA, 2005, p. 130)

Ao chamar a atenção para os milhares que estão e vivem à mercê, "uma reserva ilimitada de vítimas do inconfessável, do arbitrário, do impune, do obsceno", recordando os seres humanos que, rejeitados pela África e pela Europa, são "empurrados à pressa para uma vala comum, no Tânger, [...] cadáveres negros [...], irreconhecivelmente desfeitos em areia e sal, água e sangue, [...] ninguém viria para os identificar", a narrativa de Moura (2005, p. 88) volta a dialogar com as reflexões de Biondi sobre o corpo sofredor:

\begin{abstract}
A morte dos refugiados, por si mesma, parece ser o aspecto principal que justifica o não reconhecimento da vida/morte, assim como a não existência destas pessoas. Sua condição de refugiados e desnacionalizados é um emblema daqueles que vivem sem direitos, que não têm direito à vida [...] a tarefa para com estes sujeitos é a de exterminá-los, pois não há alternativa nesta lógica. Suas mortes servem para reiterar o predomínio do "mais forte", assim como o da vida que merece ser preservada diametralmente oposta àquela que precisa ser expulsa e exterminada. (BIONDI, 2013, p. 92)
\end{abstract}

A reportagem de Paulo Moura procura, ainda, adentrar as nuances complexas das famílias que, a partir de 1991, quando os países europeus deixaram de emitir vistos para a imigração, passaram a se dedicar ao tráfico de drogas e imigrantes, como no caso de Mohamed que, após trabalhar numa fábrica de panelas, ganhando 60 euros por mês, decidiu trabalhar, com o irmão, com emigração clandestina, faturando cerca de 42 mil euros por viagem descontando-se quase 28 mil euros com as despesas de logística e do suborno dos guardas: "os agentes da autoridade são um auxílio precioso. Por cada viagem, a polícia recebe 14 mil euros. É uma das despesas correntes do negócio. Mohamed faz as contas num papel para mostrar como, apesar da crise, o tráfico ainda é o melhor emprego que se pode ter" (MOURA, 2005, p. 78).

É tecida, também, através da descrição que sublinha os silêncios e as gestualidades dos personagens, aprofundando-se nas subjetividades que perfazem 
o contexto dos implicados na crise humanitária, tal qual evidenciado no encontro do repórter português com Karim, condutor dos "zodiacs" da família de Mohamed, em um promontório nos arredores do Tânger:

Caiu a noite, as luzes de Espanha cintilam à nossa frente. "Desde os 11 anos que trabalho no mar", Karim explica pormenores do seu ofício, seus segredos de marinheiro, apontando para vários locais do estreito. "Ao princípio ajudava os pescadores [...] Depois, era inevitável, comecei a trabalhar no tráfico, aos 17 anos". [...] Olha o mar, de diferentes maneiras e ângulos, carregados de expressão. Raramente faz gestos com as mãos. Vai contando as suas histórias cheio de intensidade dramática, como o narrador de um velho filme policial. Intercala as frases com longos silêncios, como se ficasse a pensar no que será acertado dizer, ou no que não deveria ter dito. [...] Há uma certa música nas suas palavras. Também na sua silhueta magnífica desenhada no escuro e no silêncio. Karim sabe criar um momento, sabe conduzir as circunstâncias num rumo certo, sem sobressaltos, navegando hábil, docemente, por entre os efeitos das sombras, dos pequenos ruídos circundantes. Imagino-o com a mesma serenidade a meio do estreito numa noite de temporal [...] Singular ponto de encontro de culturas, o "'zodiac" de Karim. (MOURA, 2005, p. 75)

Passaporte para o céu trata, por fim, da vida de mulheres, como Gloria, Elly, Carol, Cindy e Juliete, que percorrem, de fronteira em fronteira, muitas vezes grávidas, o caminho em busca de novas possibilidades, e acabam por encontrar abrigo nas ruas europeias de prostituição. Não trazem nada consigo, conforme explica o padre Isidoro Macias, que as recebe na cidade espanhola de Algeciras, exceto os números de telefone de contatos da máfia na Europa e um papelzinho com o nome do frade franciscano da Cruz Branca, conhecido em toda a África como padre Patera.

Até 1972, Isidoro Macias vivia em Tânger, onde dava apoio aos espanhóis exilados pelo franquismo. Quando retornou ao país, passou-se a se dedicar às mulheres africanas que desembarcam nas praias à costa de Tarifa, principalmente às gestantes ou com bebês: dá-Ihes abrigo e comida, em dois apartamentos que são propriedade da instituição de caridade Casa Familiar Virgem da Palma. Seus relatos nos colocam diante de um delicado processo que envolve a gravidez como expediente para ficar na Europa e o casamento como artifício para regularizar 
a situação dos pais da criança. "'Elas vêm grávidas porque descobriram que é a única forma de chegarem e não serem deportadas', explica o padre. E complementa: 'Eu ajudo quem precisa de ajuda. Não pergunto se é cristão ou muçulmano ou ateu. Também não quero saber se a história que me contam é verdadeira ou não'" (MOURA, 2005, p. 40). Os nomes dos bebês simbolizam a travessia das mães e o que elas esperam para os filhos: Success, Destiny, Lucky, Biggy, Blessing.

Pelo registro de suas histórias, Paulo Moura denuncia, também, os contratos que, desde a África, ludibriam as jovens que acreditam poderem mudar a realidade de seus parentes - adentrando, assim, em uma problemática a que raramente temos acesso pelos meios de comunicação tradicionais:

Com a mãe e uma tia, Juliete deslocou-se ao escritório de um advogado, na cidade de Benim. Estava nervosa, mas ao mesmo tempo excitada com a perspectiva de um novo mundo que lhe abria as portas. $O$ advogado já tinha pronto o "contrato", um documento impresso, de várias páginas, num papel timbrado, com o nome da organização - a Taskforce. Não foi preciso ler. Já todos conheciam o conteúdo do sinistro acordo: a Taskforce compromete-se a levar Juliete até um país europeu, onde lhe providenciará trabalho. Em contrapartida, ela ficará obrigada a pagar à organização, a um ritmo semanal, a totalidade das receitas do seu trabalho, após deduzido o essencial à sua sobrevivência, até perfazer uma dívida de 40 mil dólares. Até lá, Juliete não terá qualquer liberdade. Será propriedade da Taskforce, que disporá em absoluto da sua vida, por um intermédio de uma "madame", a quem entregará o dinheiro e que fiscalizará toda a sua actividade. (MOURA, 2005, p. 44)

Observa-se, deste modo, a construção de uma narrativa que, entrecruzando vozes e sentidos plurais, busca se aprofundar na complexidade do desafio planetário que se instala neste século, na tentativa de oferecer meios para que os leitores, compreensivamente, experienciem com os refugiados esse longo purgatório - "em desavença tácita com o céu, e em concorrência desleal com o inferno" (MOURA, 2005, p. 26). Para além da estrutura, semelhante a uma linha de montagem, que ordena o trajeto dos camarades e os manipula, em benefício das máfias, Moura apreende a humanidade daqueles que, infelizmente de forma mais frequente do que poderia, nos chegam como estáticas ou imagens do horror. 


\section{Considerações finais}

A luta pela sobrevivência da humanidade, ponderam Morin e Wulf (2003, p. 42), "não se trava somente em Ruanda ou na Bósnia, ou em algum outro lugar, ela acontece em cada um de nós. Nós temos um inimigo assustador que somos nós mesmos". E nessa aventura desconhecida pela qual nosso planeta navega, somente a tomada de consciência sobre o nosso pertencimento a uma pátria comum, para o pensador francês, pode nos salvar de um drama humanitário. "É preciso salvar a unidade, é preciso salvar a diversidade", defende o autor, resistindo pelo pensamento da complexidade, que se opõe ao sufocamento das outras culturas e que aceita as tensões da convivência, partindo da compreensão intersubjetiva como forma de reconhecimento desse estranho, que também habita em nós mesmos.

Complexidade essa que também reivindica contexto, que pede abertura empática ao Outro, que nos demanda, conforme Künsch (2000, p. 290), uma "reviravolta no modo de se colocar diante do mundo e das pessoas". Reafirmamos, por isso, à guisa das considerações finais, a experiência do encontro, ou do signo da relação (MEDINA, 2006), como fundamento a sustentar a atividade jornalística; sobretudo no trabalho de reportar a realidade dos que vivem à margem do interesse público e midiático, em um esforço por fazer da narrativa um registro, também histórico, das vozes tradicionalmente silenciadas - ou, por muitas vezes, esquecidas.

Evidenciamos no trabalho de reportagem do jornalista português Paulo Moura, especificamente em seu livro Passaporte para o céu, esse exercício complexocompreensivo que fomenta movimentos dialógicos (BUBER, 1982) entre repórter e fonte, mas também entre leitores e personagens, e que, assim, aproxima-nos da realidade dessas vidas nuas (AGAMBEN, 2004), ou dos corpos sofredores (BIONDI, 2013), que existem em um abismo de não-vida e de não-morte.

Destacamos, neste sentido, com o presente artigo, aqueles trechos de sua escritura que permitem identificar o gesto jornalístico de voltar-se para o Outro, na prática imersiva que partilha subjetividades e que, deste modo, configura-se 
como alternativa para se apreender, para além dos relatos noticiosos tradicionais, a crise dos migrantes refugiados do continente africano.

\section{Agradecimentos}

Tayane Aidar Abib agradece à Fundação de Amparo à Pesquisa do Estado de São Paulo (Fapesp) pela bolsa de Doutorado (Processo 2018/01541-9).

\section{Referências}

AGAMBEN, G. Homo sacer: o poder soberano e a vida nua I. Belo Horizonte: Humanitas, 2004.

BIONDI, A. G. Corpo sofredor: figuração e experiência no fotojornalismo. 2013. 220f. Tese (Doutorado em Comunicação Social) - Faculdade de Filosofia e Ciências Humanas, Universidade Federal de Minas Gerais, 2013.

BRUM, E. A menina quebrada e outras colunas de Eliane Brum. Porto Alegre: Arquipélago Editorial, 2013.

BUBER, M. Do diálogo e do dialógico. São Paulo: Perspectiva, 1982.

KRAMER, M. Prefácio. In: MOURA, P. Passaporte para o céu. Lisboa: Dom Quixote, 2005. p. 5-11.

KRISTEVA, J. Estrangeiros para nós mesmos. Rio de Janeiro: Rocco, 1994.

KÜNSCH, D. Comprehendo ergo sum: epistemologia complexo-compreensiva e reportagem jornalística. Communicare, São Paulo, v. 5, n. 1, p. 43-54, 2005. 
KÜNSCH, D. Comunicação e pensamento compreensivo: um breve balanço. In: KÜNSCH, D. A.; MARTINO, L. M. S. (org. ). Comunicação, jornalismo e compreensão. São Paulo: Plêiade, 2010. p. 14-46.

KÜNSCH, D. Maus pensamentos: os mistérios do mundo e a reportagem jornalística. São Paulo: Annablume, 2000.

LÉVINAS, E. Entre nós: ensaios sobre a alteridade. Petrópolis, RJ: Vozes, 1997.

MAFFESOLI, M. O conhecimento comum: introdução à sociologia compreensiva. Porto Alegre: Sulina, 2010.

MARCONDES FILHO, C. O espelho e a máscara: o enigma da comunicação no caminho do meio. Ijuí: Editora Unijuí, 2002.

MARTINO, L. M. S. O desafio epistemológico de compreender o outro. In: KÜNSCH, D. A.; MARTINO, L. M. S. (orgs.). Comunicação, jornalismo e compreensão. São Paulo: Plêiade, 2010. p. 7-11.

MEDINA, C. Entrevista: o diálogo possível. São Paulo: Ática, 2008.

MEDINA, C. O invisível à luz da experiência e da compreensão. In: KÜNSCH, D. et al. Comunicação e estudo e práticas de compreensão. São Paulo: UNI, 2016. p. 11-28.

MEDINA, C. O signo da relação: comunicação e pedagogia dos afetos. São Paulo: Paulus, 2006.

MORIN, E. Os sete saberes necessários à educação do futuro. 2. ed. São Paulo: Cortez, 2002. 
MORIN, E.; WULF, C. Planeta: a aventura desconhecida. São Paulo: Editora da Unesp, 2003.

MORIN, E. Além do progresso. In: MORIN, E.; WULF, C. Planeta: a aventura desconhecida. São Paulo: Editora da Unesp, 2003. p. 8-35.

MORIN, E. Introdução ao pensamento complexo. Porto Alegre: Sulina, 2007.

MOURA, P. Passaporte para o céu. Lisboa: Dom Quixote, 2005.

MOURA, P. Um olhar humano sobre o mundo. [Entrevista cedida a] João Moreira. Revista Bica, Lisboa, p. 116-124, 2017. Disponível em: https://issuu.com/ revistabica/docs/bica_1. Acesso em: 28 jun. 2021.

RESTREPO, L. C. O direito à ternura. Petrópolis: Vozes, 1998.

SODRÉ, M. A narração do fato: notas para uma teoria do acontecimento. Petrópolis: Vozes, 2009.

SODRÉ, M. As estratégias sensíveis: afeto, mídia e política. Petrópolis: Vozes, 2006.

SONTAG, S. Diante da dor dos outros. São Paulo: Companhia das Letras, 2003.

United Nations High Comissioner for Refugees. Global trends - forced displacement in 2017. UNHCR, Genebra, 2018. Disponível em: http://www.unhcr.org/en-us/statistics/ unhcrstats/5b27be547/unhcr-global-trends-2017.html. Acesso em: 20 jul. 2020.

submetido em: 13 abr. 2020 | aprovado em: 6 ago. 2020 